spleen full of blood; it contracts; there are no valves at the entrance of the splenic artery, therefore part of the arterial blood would attempt to return up that vessel, in direct opposition to the heart's impulse. But as to the greater portion of the fuid, it would pass along the splenic vein to the junction of the superior mesenteric; and as there are no valves at the entrance of that vessel, it would be driven two ways, partly into the mesenteric veins, in direct opposition to the general circulation, and partly up the portal vein to the liver. Such an arrangement would be almost as useless as the left ventricle of the heart acting without a mitral valve. I remain, Sir, yours obediently,

Liil toa-Lindsey, Feb. 1550. II. J. WaterLAxD.

\section{THE COUNCIL OF THE COLLEGE OF SURGEONS.} To the Editor of 'THE LANCET.

$S_{I R},-I t$ is to be regretted that the opportunity offered by the delivery of the IIunterian Oration, once in every year, should not be made, as was intended by the illustrious founder, a source of profit, and the means of cementing the combined interests of our noble profession! This year it was preceded, purposely, I should inagine, by an announcement from the Council of a most unjust and illiberal lind, intended, no doubt, to test the feelings of the members; offering them a stone as a substitute for bread. When $I$ couple the insincere and offensive language of the orator, $I$ am at a loss to conceive what deductions were anticipated, and what expectations realized; if the symbol of the College, as to the future, is to be a withered olive-branch, and the anchor of hope, broken, the members will vote it unanimously. They will also add a broken lute, as an insignia of the discord and want of harmony which pervade its edicts and incantations. The Council, I should think, are not musical, or they would remember the fate of Orphens, who, it is said,-

$$
\text { " But now moves nothing but his fiddle stick." }
$$

It is quite evident, however, that the perfections of the highest order of minds are unknown to the Council! despite the anuual recital and commenoration of departed virtue and acquirements, which wa i received with the usual marked respect on the present occasion, though it was quite evident there was something in subjection, and that something was the noble science, which has been so long fettered by conservative principles, which, in these days of civilization, free trade, and reform, can no longer resist the pressure of her true rotaries. It is foreign to my purpose to review, critically, the peculiar phases of an oration, intended to illustrate the bright deeds and characters of the departed; yet I cannot refrain expressing my sontiments at the mockery held out to the living.

My motive for addressing you, Sir, is to call forth, if it exist, the expiring scintillation, the last dying glimmer of good faith, from the heads or hearts of those satellites, who are revolving round the shadows, not the substance, of the mighty and regretted planets, whose memory we venerate, and whose abscnce we annually meet to deplore.

It has of tentimes been asked-What do the members require? I will now state what it appears to me we require. First, an extension of the collegiate franchise, in order that surgeons in general practice may possess the right of election to the council. I would also submit, that all students in medicine and surgery (for they cannot be separated) be admitted at a certain age, say eighteen or twenty, before they commence anatomy and surgery, to their examination in the classics, mathematics, languages, \&c., giving each successful candidate a certificate of qualification on these points, thereby disburthening their minds and improving the whole class of medical practitioners, without placing the burthen on the fellows only; in after years, their diploma to practise would be the result of future studies and theindustry exercised. As regards the council, their prodigal and unnatural bearing towards us, their own offspring, is monstrous, and, like the sin of the giants, as expressed by 'Tully, "is an actual rebellion against heaven." The generality of "your readers will recollect the information given by Homer, when Minerva removed the mist from the eves of Diomedes, in order that he might plainly distinguish both gods and menin other words, that he might discern the good from the evil. All will, no doubt, feel it their duty to call up their best efforts to operate gratuitously in removing the cataract which has become permanent in the optical delusions of the council. Oh! that they possessed the soul to exclaim, with Alcibiades, "Remove from my mind the darkness, or whatever else that obscures it; I will refuse nothing, so that I become a better man." Can modern generals or philosophers say more? Will advancement in knowledge and science say as much. Whether we are medical or legal practitioners, we must not forget that we are men-responsible, reasonable, Christian men. I would refer your readers to the tenth satire of Juvenal, and the second of Persius, which afford to the curious some interesting arguments, demonstrative of the feelings of the most refined heathens. I quote the first passage, translated by Dryden, of Juvenal's tenth satire:-
"Look round the habitable world-how few
Know their own good, and knowing it, pursue ',
I am, Sir, yours obliged, William SETh Gint.

Colebrook-tcrrace, Isiington, Feb. 25, 1850.

\section{THE JOHN HUNTER CLUB.} To the Editor of The Lancer.

SIR,-Touching the election for the secretaryship of the Royal Medical and Chiruraical Society, allow me to say, that it appears to me that Mr. Charles Hawkins has been rather hardly dealt with, being made to bear all the odium attaching to the "John-Hunter Club." I was not a member myself, but $I$ have heard that it comprised among its members a very considerable number of "Fellows." Now, I think it but fair that we should learn the names of the other members, that we may at least mete out the same measure of justice to cach that Mr. Charles IIawkins has received. Perhaps you can furnish the names. But I conclude that the gentlenen who composed the club, as they have declared they wished not for secresy, will send you their names; or perhaps Mr. Charles Hawkins, who was secretary, will furnish you with a list. I cannot be lieve what I have heard, that Mr. Erichsen was a member of the club, and lent limself to the opposition to Mr. Charles Hawkins, and was silent on this subject; and as I think Mr. Erichsen ought to have an opportunity to clear himself from the supposition, $\mathrm{I}$ consider that the names of the members of the Joln-Hunter Club should be made public. I am, Sir, yours \&c., Fiat Justitia.

* We are not in possession of the names of the members of the John-Hunter Club. If the list be sent to us, it shall be published for the information of the profession. We do not believe that Mr. Erichsen was a member of the club.-ED $L$.

\section{THE MEDICAL PROFESSION AND THE ASSURANCE OFFICES.}

To the Editor of THE LANCET.

The Industrial and General Life Assurance and Deposit Company, 2, Waterloo-place, London, Feb. $28,1850$.

SIR, - Mry attention having been called to your corvespondent's letter on the $23 \mathrm{rd}$ instant, I consider it necessary to trouble you with the following remarks, being of opinion, that, without additional information, the profession cannot fairly judge as to the propriety of accepting the fee of $2 s .6 a$. therein referred to.

This company has been established with the view of extending the benefits of life assurance to the industrial classes, by inculcating habits of saving, and affording them opportunities of making provision for their wives and families, hitherto unattainable by that large and important class-thus,

By a weekly payment of 1 s., a person twenty years of age may assure $11493 \mathrm{~s}$. If thirty years of age, $\pm 118 \mathrm{~s}$.; and if forty years of age, $£ 89 \mathrm{Ts}$, , to be paid to their families at death. By a monthly payment of $1 s$, a person twenty years of age

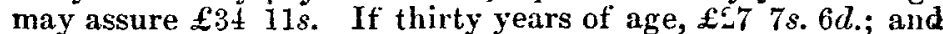
if forty years of age, $£ 2013 s .6 d$., to be paid to their families in like manner.

By a quarterly payment of $1 s$, a person twenty years of age may assure $\mathfrak{E} 11$ 12s. $6 \mathrm{l}$. If thirt $y$ years of age, $£ 94 \mathrm{~s} .9 \mathrm{l}$.; and if forty years of age, $£ 619 s$, to be in like mauner paid at deatl..

Under the " deposit" or " accumulative" system also,

A person, aged twenty, on payment of $\mathfrak{f}_{3} 9 \mathrm{9} .9 \mathrm{~d}$. will receive a policy, assuring $£ 10$ at death, (on which policy no further payment whatever is required, and after the first year may receive back $£ 39 s$. 9d., or after the sixth year, $£ 3158.2 d$, as shown in table, and surrender the policy; or may borrow the full amount of premium paid at the usual interest, on security of the policy only, repaying the loan at convenience.

The directors coincide in opinion with your correspondent, 